\title{
DEFINITION OF CONTACT STRESS IN FRICTION UNITS ON THE BASIS OF THE ACOUSTIC EMISSION METHOD
}

\author{
Sergay Filonenko, Viacheslav Stadnychenko, Anzhelika Stakhova \\ National Aviation University \\ 1 Cosmonavta Komarova Ave, Kiev, Ukraine \\ E-mail: eduicao@nau.edu.ua
}

Received 24 April 2009; accepted 10 August 2009
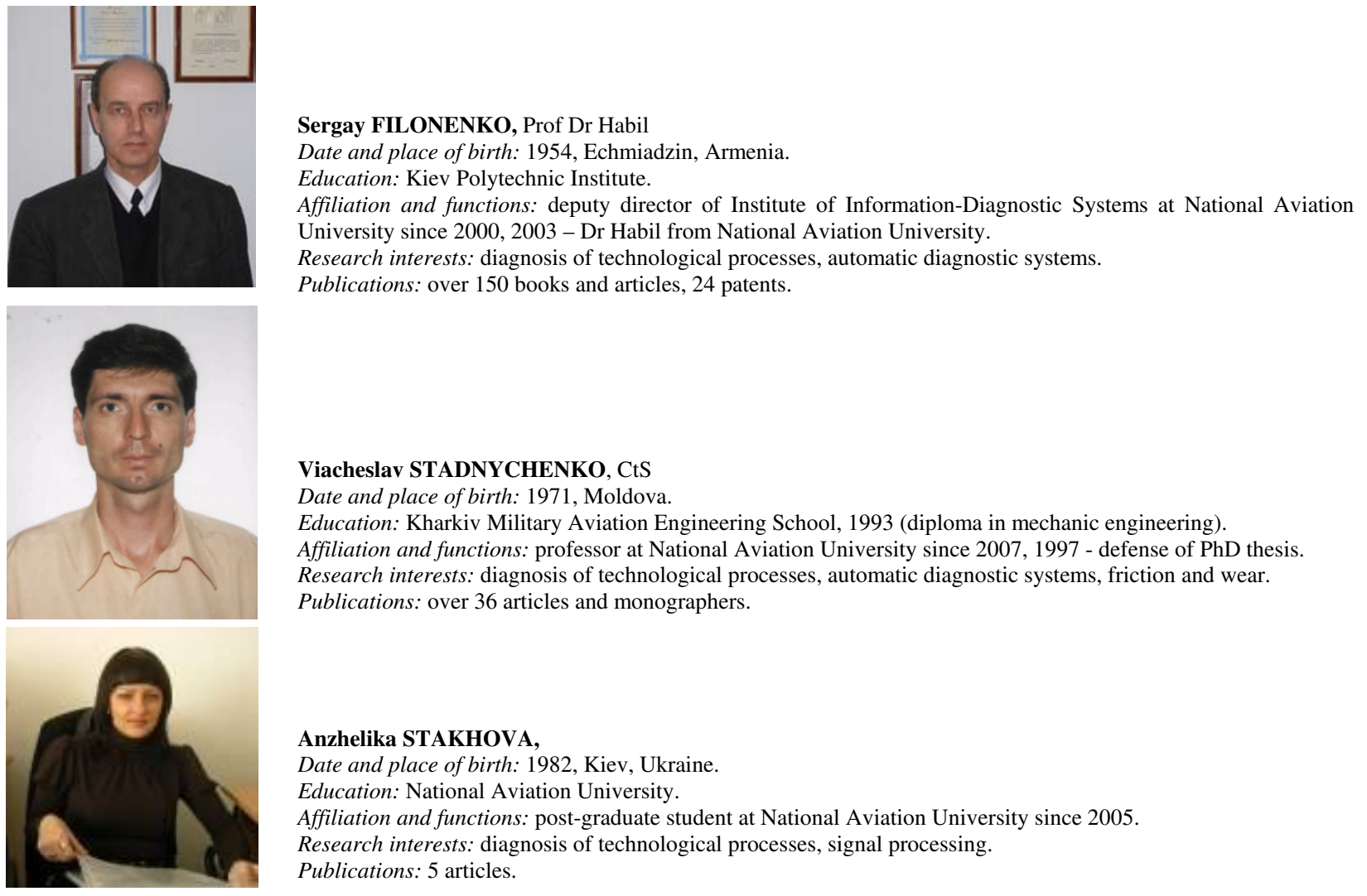

Anzhelika STAKHOVA,

Date and place of birth: 1982, Kiev, Ukraine.

Education: National Aviation University.

Affiliation and functions: post-graduate student at National Aviation University since 2005.

Research interests: diagnosis of technological processes, signal processing.

Publications: 5 articles.

\begin{abstract}
The following results of acoustic emission signals researches were obtained during the change in contact stress. It is shown that the theoretical regularity of change in average level of the acoustic emission resulting signal at contact stress has a linear character. Analogical regularity is received during experimental researches. It is showed that the sensitivity of the acoustic emission method and the precision of determining contact stresses are considerably better, than the tensometry method. The recording of the moment when friction unit seize begins is also considerably more precise.
\end{abstract}

Keywords: acoustic emission, modelling, contact stress, signal amplitude, friction unit, destruction, seizure, diagnosis. 


\section{Introduction}

The acoustic emission method (AE) has extensive application on the basis of research of friction processes (Сверидюк $и$ др. 1987, Трибология... 1993, Morris et al. 2002, Harvey et al. 2001, Wang et al. 2003). This is caused by its sensitiveness to change in high wear mechanisms, and the possibility of receiving information about the kinetics of the destructive processes of contact surfaces. Hence, the principal research directions are the regularities of $\mathrm{AE}$ radiation and parameters of $\mathrm{AE}$ signals' for the development of technical diagnostic methods and monitoring of friction units. First of all, this concerns the exposure of the friction unit transition from the normal stage to the stage of catastrophic wear-out. Not only empirical regularities but also theoretical research results, which allow a picture of $\mathrm{AE}$ signals emission to be formed depending on the way, how these signals were created, are interesting in this case. Taking into consideration these ideas it is possible to identify processes, that take place in the surface layers of materials and to control the processes that cause friction units to wear out.

A significant amount of researches concerning $\mathrm{AE}$ during friction, are based on experimental ground. They are based on search of AE interconnection with traditional parameters that characterise the processes of friction and wearing out. Friction coefficient, contact stress, friction moment, threadbare material volume, rotation frequency, friction path length, friction contact area are used as such parameters. Other are regarded as traditional parameters (Tanaka et al. 2004, Tan et al. 2005, Guzik et al. 2006, Benabdallah 2008, Дубровин и др. 2004, Дроздов $и$ дp.1981). As a rule, during the processing of AE signals, recording rate and root mean square value (RMSV) are analysed. RMSV is, however, a basic parameter in accordance with the new trends. The reason is that the AE signal, registered on the sensor output, is a continuous signal.

At the same time, limit value threshold of recording rate processing is used for continuous signal transformation in the impulsive sequence of signals. The choice of the limit value threshold is arbitrary, without any theoretical grounds. In consideration of the system response to the change in the wear conditions during the friction process (increase or decrease of AE signal amplitude), its application results in the considerable distortion of the registered information.

The empirical regularities of the friction parameters of AE signals caused by the test conditions, which are, as a rule, laboratory conditions, and not suitable for the diagnosis of friction units in operation. The absence of researches regarding $\mathrm{AE}$ during friction should also be taken into consideration. This does not allow modelling the AE signals emission during various scenarios of material wears and makes it more difficult to discover factors influencing these processes.

It considerably complicates the set up of physical experiments and research of means for friction units condition estimation and their transition from the normal stage to the stage of catastrophic wear. For example, one of the characteristics observed during research of the friction process, is contact stress. The strain gauge transducers are placed on one of the friction unit samples, and that is applicable only in laboratory.

In following research-modelling $\mathrm{AE}$ signals during the normal wear process will occur during the change in the contact stress. It will be shown, that the average amplitude regularity of the resulting $\mathrm{AE}$ signal depends on contact stress linearly. As it will be shown, the experimental regularity of the average amplitude of the registered AE signal during of normal wear has good compliance with the theoretical values. This allows the contact stress arising in the working friction unit to be precisely defined.

\section{Theoretical aspect}

Investigation conducted during research, has allowed developing a model of the AE signal that forms during the wear process of material overlays (Бабак $u \partial p$. 2007). It is based on single signal models AE that arise during friction at plastic deformation or destruction of certain friction contact areas (Filonenko et al. 2008a). Thus, the AE resulting signal looks like

$$
\begin{gathered}
U^{\prime}(t)=\sum_{i} U_{0} \delta_{0} \sigma_{0 e}^{3} e^{4 z\left(t-t_{i}\right)} e^{-b \sigma_{0 e} e^{z\left(t-t_{i}\right)}}+ \\
\sum_{j} U_{0 d} \varepsilon_{0 d} e^{r\left(t-t_{j}\right)} e^{-B \varepsilon_{0 d} e^{r\left(t-t_{j}\right)},}
\end{gathered}
$$

where $t_{i}, t_{j}$ - the random moments of AE signals occurrence time during type II (the first component) and type I (the second component) destruction; $U_{0}=k N_{0} c z-$ the maximum possible displacement during destruction without disperse in durability of $S_{\mathrm{T}}$ inhomogeneous layer located in the contact platform; $k$ - proportionality factor; $N_{o}$ - the elementary volumes quantity in inhomogeneous layer $S_{\mathrm{T}} ; c, b$-durability distribution factors of elementary volumes (depending on the physical and mechanical characteristics of material); $\sigma_{0 e}-$ initial equivalent pressure; $t$ - time; $z=E / \xi ; \xi$ - viscosity factor; $E$ - the elasticity module; $\delta_{0}$ - average duration of disturbance impulse during elementary volume destruction; $U_{0 d}=a_{0} M \frac{v_{d}}{\ell_{0}} \delta_{d}-$ displacement amplitude that depends on physical and mechanical material characteristics; $a_{o}-$ single compensation impulse amplitude during displacement (this is constant and does not depend on deformation); $\ell_{0}$ - distance between two single disposition radiation certificates; $v_{d}$ - displacement of the average speed (this is considered a constant); $\varepsilon_{0 d}-$ initial relative deformation; $\delta_{d}$ - average duration of indignation impulse during disposition; $M, B, r$ - constants (which depend on the physical and mechanical material characteristics).

For AE a signal modelling during normal wear the friction pair with constant rotation speed in accordance with (1) indicates that with the increase of deformation 
caused by stress, both the average amplitude and the range of the resulting $\mathrm{AE}$ signal increase. The received results correspond with experimental data (Filonenko et al. 2008a). At the same time, analysis of prevailing wear mechanism influence on AE signals allowed us to establish that the basic contribution to the amplitude of the resulting AE signal comes from the signals formed at structures of type II destruction (Filonenko et al. 2008b). In figure 1 fragments of the modelling results of AE signals in the prevailing wear mechanism for the chosen scenario of the types I and II destruction are shown.

$\widetilde{U}_{1}$

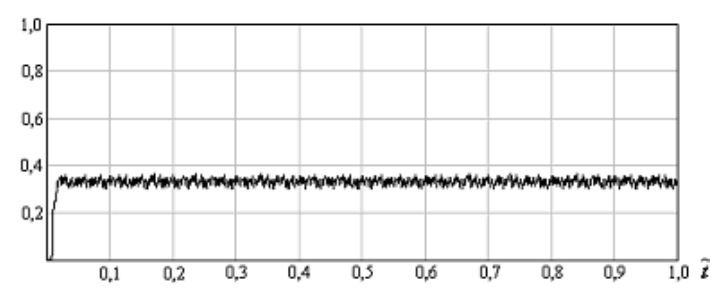

$\widetilde{U}_{1,}$

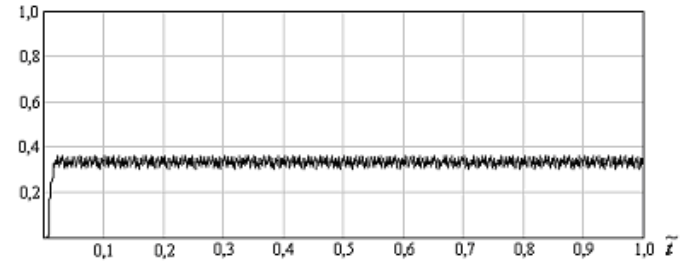

$\widetilde{U}_{2}$

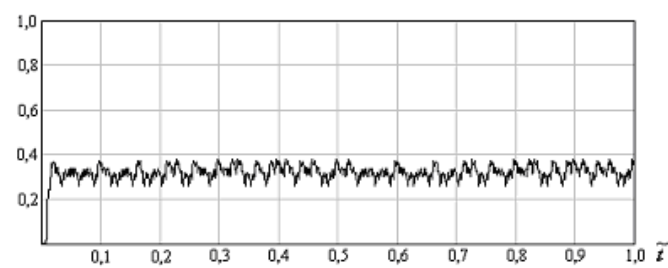

$\widetilde{U}_{2}$

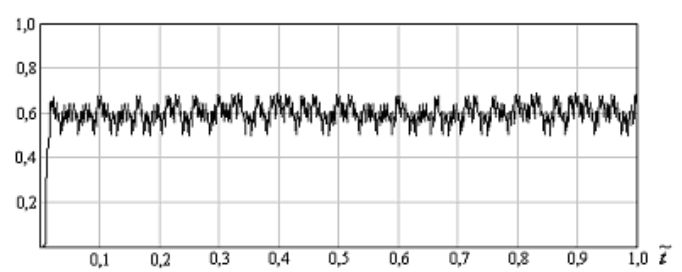

$d$

Fig 1. Resulting AE signals during the normal friction pair wear at the prevailing mechanism of wear: $a$ - the destruction of type I structures; $b, c$ - the destruction of type II structures. The starting time of the destruction of each subsequent structure type (I or II) is permanent and equals to 0.004 , but plastic deformation unit values vary. Values $B$ and $b$ are equal to $B=10, b=10 . \widetilde{U}-$ the normal meaning for $U_{\max } \cdot \tilde{t}$ - the standardized meaning for $t_{\max }=$ const . Values $\varepsilon_{0 d}$ and $\sigma_{0 e}$ are equal to $a$, where $\varepsilon_{0 d}=11 ; \mathrm{b} \varepsilon_{0 d}=15 ; \mathrm{c}-\sigma_{0 e}=11 ; \mathrm{d}-\sigma_{0 e}=15$
Analysis of type I structures indicated that at $\varepsilon_{0 d}=$ 13 the value of the average amplitude of the resulting $\mathrm{AE}$ signal, regarding value $\varepsilon_{0 d}=11$, increased and was equal to $0.6 \%$, when $\varepsilon_{0 d}=15$ it increased up to $2 \%$ (Fig 1, a, b). Thus, range of amplitude went up $4.4 \%$ and $5.8 \%$, respectively.

For the structures of type II at $\sigma_{0 e}=13$, the value of the average amplitude of the resulting AE signal, regarding value $\sigma_{0 e}=11$, increased for $41 \%$, and at $\sigma_{0 e}=15-$ for $86 \%$ (Fig 1, c, d). Thus, the range of the amplitude is increased, in accordance with it, by $19 \%$ and by $36.7 \%$.

In the first case, resulting change in the range of average amplitude of the AE signal is explained below. As deformation increases pulse signal compression occurs for a period of time without amplitude change (Бабак $u$ $\partial p$. 2007). In the second case, the increase in amplitude of the impulse signal is observed during stress increase, with their simultaneous compression in time. In both cases, signal compression leads to the change in overlapping time conditions and different contribution of instant amplitudes to the amplitude of the resulting signal.

When two wear processes coincide, change in overlapping conditions of the impulse signals appears at the more abrupt change of resulting AE signal parameters. First of all, this concerns the increase in the range of its amplitude. Thus, the lowest level range for the amplitude is determined by the amplitude range of the AE signal impulse formed during the destruction of type I structures, and the highest level - is determined by the amplitude of the impulse signals formed during the destruction of type II structures. At the same time, the modelling showed (Filonenko et al. 2008a, Filonenko et al. 2008b), that with the increase of the stress deformation in friction unit's surfaces an increase in the average level of the AE signal amplitude is observed. In accordance with this data, its value depends on contact pressure or contact stresses.

The correlation between resulting average level of $\mathrm{AE}$ amplitude and contact stress received in accordance with modelling, is shown in figure 2 . The regularity (fig. 2) is presented in relative values: $\widetilde{\widetilde{U}}=\bar{U}_{T} / \bar{U}_{m}$, $\tilde{\sigma}=\sigma_{T} / \sigma_{m}$, where, $\bar{U}_{T}, \bar{U}_{m}-$ are the current average levels of resulting AE signal amplitude and its maximum value; $\sigma_{T}, \sigma_{m}$ - the current value of contact pressure and its maximum value. If we take into account the constancy of the contact platform, it is possible to move from contact stress to contact loading $(\widetilde{P})$.

The results (Fig 2) indicate that the regularity of the resulting AE signal amplitude average level during contact stress has linear character and is described by the following formula:

$$
\widetilde{\bar{U}}=A+B \widetilde{\sigma}
$$

where $A$ and $B$ - factors of approximating expression (in fig. 2 the values of $A$ and $B$ are equal $-A=-0.81$, $B=1.8) ; \tilde{\sigma}-$ contact pressure in relative values. 


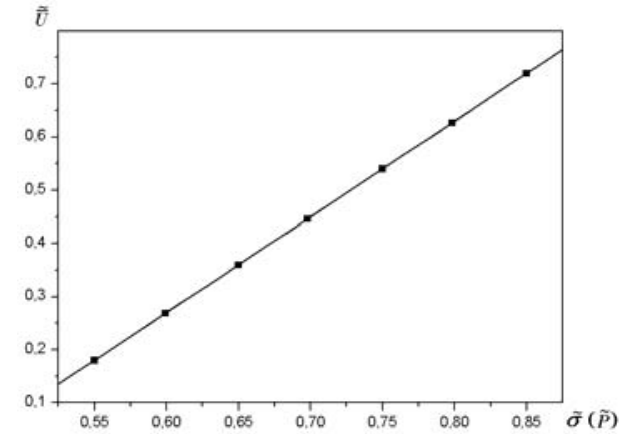

Fig 2. The regularity of the resulting average amplitude of the $\mathrm{AE}$ signal from the value of contact stress expressed in relative values. Data processing was carried out by the modelling results, in accordance with (1)

\section{Experimental research}

The experimental research of AE signals was performed by means of the CMT-1 friction device by means of steel 12X2H4A samples. A "roller-roller" ("diskdisk") kinematics pair was used. The gear lubricant Б-3B was used for lubrication. The methods and the scheme of experiment are similar to those that are described in (Filonenko et al. 2008a).

In accordance with the selected kinematic scheme, one of the friction pair samples was slower than the one that was rotating on the spindle of the CMT-1 device (Fig 3). Friction mode of rolling was used with $20 \%$ slippage. The samples dimensions of the were following: diameter $D=25 \mathrm{~mm}$, thickness $h=15 \mathrm{~mm}$. The rotation speed of the friction device (CMT-1) shaft was $V=500$ rpm. The operational stress in contact interaction of the friction pair $\sigma_{P}$ was changed from $400 \mathrm{MPa}$ to $1000 \mathrm{MPa}$ at increments of $200 \mathrm{MPa}$. The increase in operational stresses was carried out by a clamping mechanism providing the adjustment of the immovable sample position. Experiments were performed at the stage of the normal wear process, i.e. after friction pair aging.

During the friction pair tests, the contact stresses were recorded be means of strain gauges (Fig 3,6).

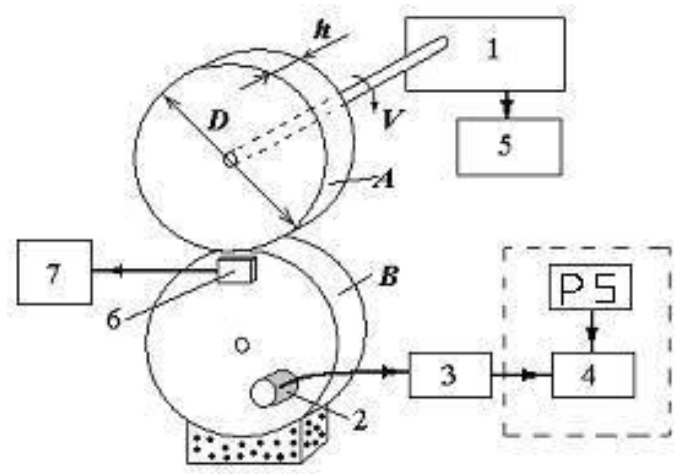

Fig 3. AE signal research method for the friction pair is the kinematic scheme "roller-roller" ("disk-disk"): $A$ is a movable sample; $B$ is stationary sample; $D$ and $h$ are sample diameter and thickness; $V$ is movable sample rotation speed; $l$ is the CMT-1 universal friction device; 2 is the AE signal transducer; 3 is the preliminary amplifier; 4 is the mobile computer; 5 is the friction moment gauge and PS is the program software
The strain gauge transducers were installed on stationary sample near the contact area. After their amplification, the signals from the strain gauge transducers were transmitted to the personal computer, which processed the amplitude of the electric signal with contact stresses size determination (Fig 3, 7). Processing results were represented in digital form and as graphic where regularity curve of contact pressure changes varies depending on time. At the same time the evaluation of contact stress and the processing of the resulting AE signal were carried out. It was done by means of an AE piezoceramic signaller (Fig 3,2), which was installed on the stationary sample on a layer of acoustic-transparent lubrication. After amplification with the preliminary amplifier (3), the AE signal was transmitted to the mobile computer (4) and subsequent processing was carried out by means of software. Processing results were represented in digital form and in the form graphic where regularity curve of contact pressure varies depending on of time. Typical results of the graphic representation of the information are considered (Filonenko et al. 2008a). Analysis of the results shows that the experimental regularity for the average amplitude of the resulting AE signal due to contact stress had a linear character (Fig 4, 1), as it is given below:

$$
\bar{U}_{A}=A_{1}+B_{1} \sigma_{K} \text {, }
$$

where $A_{1}$ and $B_{1}$ - approximating expression factors (for data given in figure 4 curve 1 values of factors $A_{1}$ and $B_{1}$ are equal $-A_{1}=-10.71, B_{1}=0.046$ correspondently); $\sigma_{\mathrm{K}}-$ contact pressure. Thus the standard deviation for probability $p=0.9997$ gives $s^{2}=0.1554$.

Results of processing of stress in strain gauges input are given in figure 4, curve 2. This regularity (Fig 4,2) is similar to the regularity received for the average amplitude of the AE signal (Fig 4, 1). It is described by a linear function of type (3). The values of factors therefore amount to $A_{1}=-2.453$, and $B_{1}=0.00819$, and the standard deviation for probability $p=0.9815$ is $s^{2}=0.5153$. At the same time, sensitivity to the alteration of the strain gauges stress, and consequently, resolution, is six times less, than the sensitivity of the AE signals.

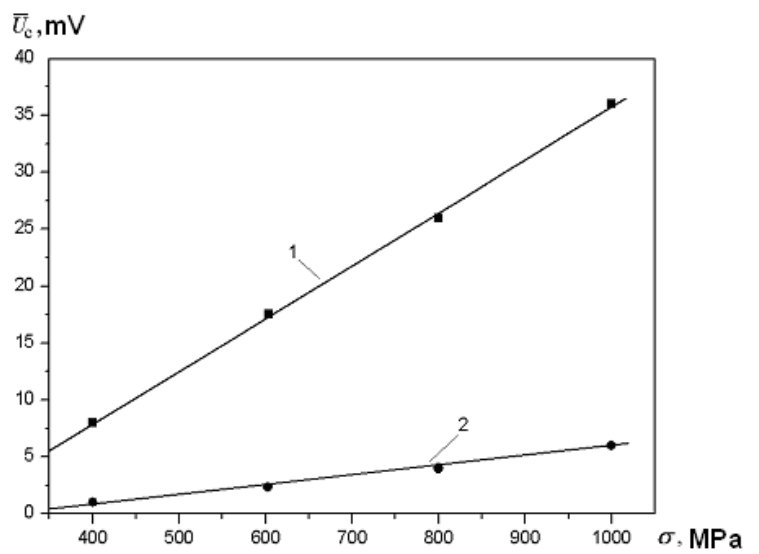

Fig 4. Regularity of the average amplitude of the AE signal (1) and the strain gauge transducer signal (2) from the unit value of contact pressure 
This regularity (3) allows the inverse regularity, which describes contact pressure from the level of the average amplitude of the AE signal, to be received. The results received data (Fig 4, 1) showed, that the inverse correlation is described by the linear function:

$$
\sigma_{K}=C+D \bar{U}_{A}
$$

where $C$ and $D$ - factors of approximating expression (the unit values of factors $C$ and $D$, are equal: $-C=236.35, D$ $=21.61$ ). Thus the standard deviation of probability $p=$ 0.9987 is $S^{2}=24.94$.

The analogous regularity (4) is also obtained be means of stress measurement with the strain gauge transducere. Thus, the unit value of approximating factors is: $C=314.19, D=117.62$, and the standard deviation for probability $p=0.9815$ is $s^{2}=62.55$.

The regulatory described in (4) allows the contact pressure at any moment of the friction pair work to defined. The given problem is important during the choice of materials for friction units, the optimisation of operating modes, the choice of lubricants, and diagnosis of the friction units. In the latter case, the definition of contact pressure at the moment of seizing (the transition of the friction pair from the normal stage to the stage of catastrophic wear process) is very important.

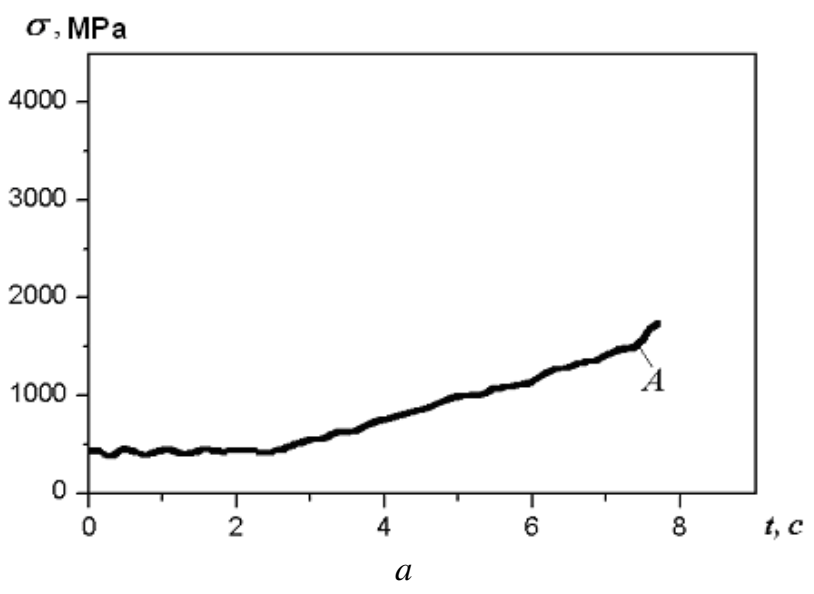

$\sigma, \mathrm{MPa}$

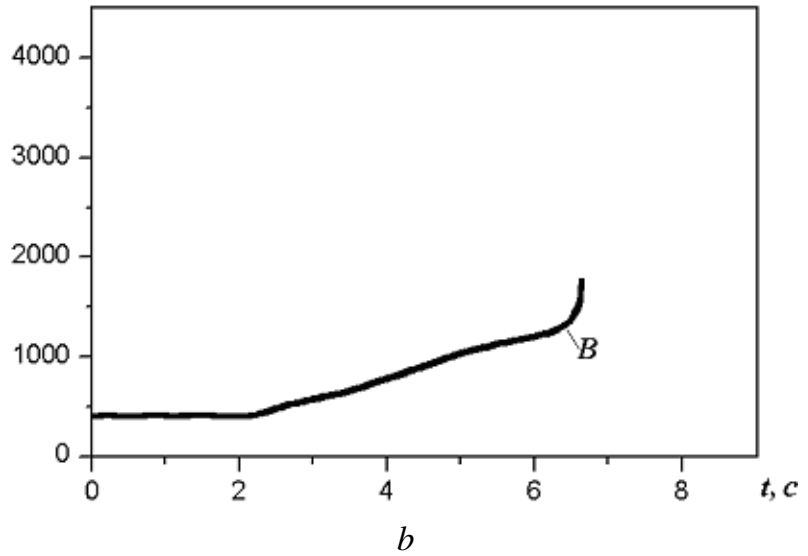

Fig 5. Contact pressure regularities that change with time, received by processing of signals from the strain gauge transducer $(a)$ and the average amplitude of the AE resulting signal $(b): A$, $B$ - the moments of seizure defined, accordingly, using the signal from strain gauge transducer and the AE signal.
For the definition of contact pressure in friction unit when it seizes experiment was carried out by means of the abovementioned methods. Pressure was constantly being increased after friction pair aging was applied. When pressure was increasing the AE signals and strain gauge transducer signals were measured and analysed. The research results about contact pressure regularities that change with time, are shown in figure $5 a$ and $5 b$, while processing average amplitude of $\mathrm{AE}$ signals and signals from the strain gauges output correspondently. Points $A$ and $B$ in figure 5, $a, b$ are the definition points of contact pressure at the moment of seizing. The results of the research showed that the regularity of the pressure over time, measured by means of strain gauge transducers has a jagged character (Fig 5, a) while the stress regularity defined by the AE signal has a smooth character (Fig $5, \mathrm{~b})$. The initial segments of regularities are linear and correspond to the stage of normal wear. At the linear increase under external loading the linear increase in regularities is observed. At the moment of seizing the regularity deviation from the linear character of their change is observed. AE resulting signal processing demonstrated a spasmodic increase in contact pressure (Fig 5, b), while the results of processing signals received from strain gauge transducers, have shown smooth nature of contact pressure change (Fig 5, a). It should be noted that friction pair seizure occurred at different moments in time. It is fixed at 6,4 minutes (Fig $5 b, \mathrm{~A}$ ) by the AE resulting signal and at 7,5 minutes (Fig 5a, B) after the beginning of recording and processing of the signals from the strain gauge transducers. Actually, using the AE resulting signal, the moment of seizing was fixed 1,1 minutes earlier. Thus, the contact pressure that was defined by means of $\mathrm{AE}$, is $1410 \mathrm{MPa}$ (Fig 5b, A), and its unit value defined by strain gauges signals, is equal to $1560 \mathrm{MPa}$ (Fig 5a, B).

The results indicate that the contact pressure seizure of friction unit is defined $15 \%$ earlier when AE resulting signal processing is used, i.e. at the initial stage of its occurrence. Thus, the value of contact pressure was defined $10 \%$ more precisely using AE signals processing, than processing of signals from strain gauge transducers.

\section{Conclusion}

The results of $\mathrm{AE}$ signals investigation during the change of the stress-deformed condition of contact interconnection surfaces showed, that the main contribution to the amplitude of the resulting signal is caused by AE signals formed during the destruction of type II structures. Thus, the regularities change of parameters and the form of the resulting AE signal change are caused by the regularities change of the parameters and overlapping conditions for impulse signals during destruction of types I and II structures. The lowest and highest levels of dispersion and the average value of the AE signal amplitude with the stress-deformation increase are actually defined by difference in influence of impulse signal amplitude. Thus, as the results showed, the correlation between the average level in AE resulting signal amplitude and the contact stress rate has a linear character. Similar regularity is re- 
ceived during experiments with the friction pair during the normal wear stage. The AE method sensitivity to the change in contact pressure is six times higher, than in case of the tensiometry method. At the same time, processing the average level of the AE resulting signal allows the contact pressure to be defined at any moment, including the beginning of seizing, with better accuracy.

It is necessary to note that the results are very interesting regarding the choice of materials for friction units, the improvement of their work and diagnosing the condition of the friction units. The application of AE allows the contact pressure to be defined with greater accuracy. Thus the processing of the resulting signal is possible to carry out not only in the laboratory, but also under production conditions, and that is almost impossible by means of the tensiometry method. Fixing the initial stage of seizing occurrence allows the friction unit work to be stopped in ahead of time, thereby preventing its destruction.

\section{References}

Benabdallah, H. 2008. Friction wear and acoustic emissions of some plastics sliding against $\mathrm{Si}_{3} \mathrm{~N}_{4}$. Wear, 264(1-2): 152-156.

Filonenko, S. F.; Stadnychenko, V. M.; Stakhova, A. P. 2008. Modelling of acoustic emission signals at friction of materials' surface layers. Aviation, 12(3): 87-94.

Filonenko, S. F., Stakhova, A. P., Kositskaya, T. N. 2008. Modelling of the acoustic emission signals for the case of material's surface layers distraction in the process of friction. Вісник $H A Y$, (2): 28-24.

Guzik, J., Wojtyniak, M., Marczak, M. et al. 2006. Investigation of acoustic emission signal generated in the friction pair lubricated with oils various lubricity additives. Eng. Trans., 54(2): $159-166$.

Harvey, T.J.; Wood, R. J. K.; Denuault, G. et al. 2001. Investigation of electristatic charging mechanisms in oil lubricated tribo-contacts. Tribology Unternational, 35(9): 605-614.

Morris, S.; Wood, R. J .K.; Harvey, T. J. 2002. Use of electrostatic charge monitoring for early detection of adhesive wear in oil lubricated contacts. ASME Journal of Tribology, 124(2): 288296.

Tanaka, H.; Yonemura, S.; Tokisue, Y. 2004. Slider dynamics during continuous contact with textured and smooth disks in ultra-low flying height. IEEE Trans. Magn..37(2): 6278-6296.

Tan, C. K.; Mba, D. 2005. Identification of the acoustic emission sours during a comparative study on diagnosis of a spur gearbox. Tribol. Intern., 38(5): 469-480.

Wang, L.; Wood, R.; Harvey, T. et al. 2003. Wear performance of oil lubricated silicon nitride sliding against various bearing steels. Wear, (255): 657-668.

Бабак, В. П.; Філоненко, С. Ф.; Стадниченко, В. М. и др. 2007. Моделі сигналів акустичної емісії при руйнуванні поверхневих шарів пар тертя. Проблеми тертя та зношування. Вип. 47, 3-8.

Дроздов, Ю. Н.; Арчегов, В. Г.; Смирнов, В. И. 1981. Противозадирная стойкость трущихся тел. М.: Наука, 139 с.

Дубровин, А. М.; Комков, О. Ю.; Мышкин, Н. К. 2004. Анализ акустической эмиссии на микротрибометре возвратно-поступального типа. Трение и износ, 25(4): 363-367.

Сверидюк, А. И.; Мышкин, Н. К.; Калмыков, Т.Ф. и др. 1987. Акустические и электрические методы в триботехнике. Мн.: Наука и техника. 280 с.

Трибология: Исследования и приложения: опыт США и стран СНГ. 1993. М.: Машиностроение; 454 с.

\title{
KONTAKTINIŲ ITEMPIMŲ NUSTATYMAS TRINTIES MAZGUOSE AKUSTINĖS EMISIJOS METODU
}

\author{
S. Filonenko, V. Stadnychenko, A. Stakhova
}

S a n tra k a

Nagrinèti akustinès emisijos galutinio signalo rezultatai kintant kontaktiniams įtempimams. Nustatyta, kad akustinės emisijos galutinio signalo vidutinio lygio kitimo teorinè priklausomybė nuo kontaktinių įtempimų yra tiesinė. Analogiška priklausomybė gauta ir eksperimento metu. Taip pat nustatyta, kad akustinès emisijos metodo jautrumas ir kontaktinių ịtempimų nustatymo tikslumas yra kur kas geresnis nei tenzometrijos metodo. Be to, kur kas anksčiau fiksuojamas laiko momentas, kai pradeda strigti trinties mazgas.

Reikšminiai žodžiai: akustinė emisija, modeliavimas, kontktinis itempimas, signalo amplitudė, trinities mazgas, suardymas, strigimas, nustatymas. 